\title{
A rendvédelmi elvárások tükröződése négy ország rendőrtiszt képzésében.
}

Az Európai Unió négy tagországa rendőrtiszt képző intézményének helyzetével, tantervének bemutatásával szeretnék kapcsolódni a militarizmus- demilitarizáltság témaköréhez. Álláspontom szerint a tananyagszerkezet szemléletes módon bizonyítja, hogy mára a rendőrséggel és az ahhoz kapcsolódó tisztképzéssel szemben támasztott követelmények jelentős mértékben nemzetközivé váltak, az európai uniós egységesülés, valamint a polgári felsőoktatás hatásai a föiskolai szintű rendőrtisztképzést a legtöbb uniós országban, tartalmában és szervezeti formáiban messze eltérítették minden militáns vonástól. ${ }^{1}$

Tekintettel arra, hogy a kiképzés, a felkészítés a jövőnek szól, az is nyugodtan kijelenthető, hogy a ma és a holnap rendvédelmi eröit a demilitarizáltság jellemzi, illetve fogja jellemezni, ezt az oktatási programok belső tartalma egyértelmüen tanúsítja. Amint a németek mondják, „,polgárbarát rendőrség vagyunk”, vagy egy másik megfogalmazásban „a rendőr egyenruhás állampolgár”. rendőrtől fellépésében és munkamódszerében távol áll minden katonai jelleg, ne tévesszen meg senkit az egyenruha viselése. Egyébként az állomány meghatározó része polgári ruhás munkakörben dolgozik. A képzés filozófiája rendvédelmi területen messze áll a katonai felkészítés elvárásaitól, elveitöl. Ez még a készenléti rendőrség kötelékeire is vonatkozik, még ha esetleg létezik néhány formai hasonlóság, egyenruhák, vagy az ilyen szervezetekre jellemző komolyabb felszerelés és technika. Akikkel szemben fellépnek, azok a saját állam polgárai, nem a katonai szempontok alapján ellenségnek besorolt személyek. Ezért a velük szemben alkalmazott módszerek is rendvédelmi és nem hadi jellegüek. ${ }^{3}$

Közismert, hogy az Európai Unió, a rendvédelem témakörét eredetileg az egyes tagországok belső ügyének tekintette. Ehhez kapcsolódóan az erre a területre vonatkozó jogszabályok az úgynevezett harmadik pillérbe kerültek, az egyes államok önállóan szabályozták a témakört. Az élet rövid időn belül bebizonyította, hogy a közös gazdaság fellendülése nyomán minden irányból új gondok keletkeznek - így a rendvédelem területén is - melyre csak együttesen lehet eredményes választ találni. Egymást követték a rendvédelmi jellegü egyezmények, szabályzások, melyek a második pillérbe kerültek, azaz valamennyi tagállam rendőrségére, rendvédelmi szervezeteire kötelezőek. Az új előírások a tanintézetek részére új típusú tananyagot, a rendőrségnek új munkaformákat és feladatokat jelentenek. ${ }^{4}$

A Bel- és Igazságügyi Miniszterek Tanácsa folyamatosan tárgyalja a felmerülő kérdéseket, tesz javaslatokat a szabályzásra, egymást követően jelennek meg az Európai Közösség rendvédelmi vonatkozású rendeletei és irányelvei. Már a rendőrség egyenruhájának színére (kékre) is született ajánlás az egész uniós területre. A német rendőrségek is elkezdték lecserélni a régi zöld-sárga öltözetet. Az irdatlan mennyiségü közösségi jogszabály magában kiszélesítette az oktatandó tananyagot. Egyéb tényezők szintén közvetlen hatással vannak a rendvédelem napi munkájára. Előtérbe került az egyén, az állampolgár személyes jogainak a korábbinál hatékonyabb biztosítása. Az Európai Unió tagországai állampolgárainak szabad utazása és tartózkodása lényegében szinte a magyar állampolgárhoz hasonló jogokat eredeztet a Magyarországon megforduló külföldiek részére is. Kényesen szükséges ügyelni a velük szemben folytatott eljárások jogszerü voltára. Felértékelődött az idegen nyelv tudása, kimondottan az angolé. Gyakoribb lett a külszolgálat az ENSZ vagy az EU égisze alatt, a fiatalok szakmai és anyagi okokból tömegesen pályáznak ezekre a lehetőségekre. Időközönként menekülthullámok érik el Európát. Kezelésük, a személyek befogadása vagy visszairányítása, nagytávolságú toloncolások, befogadó állomások müködtetése korábban nem okozott súlyos problémát, mára azonban egy pillanat alatt azzá válhat. Az internetes bünözés, az államhatárokon átnyúló gazdasági bünözés, kábítószer csempészet, emberkereskedelem, mind feldolgozandó témák az iskolák részére.

A felsőfokú rendvédelmi felkészítés belső tartalmára továbbá meghatározó az elmúlt húsz év technikai fejlődése, mely új ismereteket és eljárásokat, szakmai fogásokat hozott a napi munkába és oktatásba. Ilyenek a DNS-el történő bizonyítási eljárás, számítástechnikai adatbázisok létrehozása és ezekből történő keresés, bünügyi profilok készítése, stb.. Mindezek a kriminalisztika és az informatika tantárgyak jelentőségét növelték.

A legtöbb nyugat-európai országban lezajlott vagy folyamatban van az önálló rendészettudomány elismerése, ${ }^{5} \mathrm{~s}$ annak alapjain egyetemi szakok alapítása, a Ph.D. képzés megindítása. Ezzel kialakul a háromszintü rendőri felsőoktatás, (BA, MA, Ph.D.). 
Az elmúlt húsz év jelentős szervezeti átalakításokat hozott a környékbeli államokban, melyek során félkatonai jellegü rendvédelmi szervezetek szüntek meg, a rendőrségek közelebb kerültek a polgári közigazgatáshoz. Eltünt a cseh, a szlovák határörség, a magyar határőrség pedig beolvadt a rendőrségbe, ahogyan az Osztrák csendőrség integrálódott az Osztrák Rendőrségbe, a Német Szövetségi Határőrségből pedig létrehozták a Német Szövetségi Rendőrséget, megszünt a továbbá a Bajor Határrendörség. ${ }^{6}$

A vizsgált négy — rendőrtisztképzést megvalósító - felsőoktatási intézmény:

- Rendőrtiszti Főiskola, Budapest;

- A Szlovák Rendőr Testületi Akadémia, Pozsony;

- A Cseh Köztársaság Rendőr Akadémiája, Prága;

- A Berlini Gazdasági és Jogi Főiskola.

A négy föiskola nappali tagozatos akkreditált bachelor rendör tisztképzést folytat, ahol a felkészítés célja az, hogy a hallgatókat alkalmassá tegyék az első tiszti beosztásban végzendő munkára. Ebből következően relatíve egyszerü a viszonyok összehasonlítása, a közös pontok, illetve az eltérések feltárása. Szerettem volna kutató munkámba bevonni az osztrák rendőrtisztek felkészítését végző Bécsújhely-i (Wiener Neustadt-i) szakföiskolát, ahol polgári felsőoktatási intézményben lényegében egy rendvédelmi tanszék működik. Munkájuk két fontos vonatkozásban eltér az előző iskoláktól, csak levelező felkészítést folytatnak, és csak gyakorlott tiszthelyettes állományt iskoláznak be. Ezek a tényezők jelentősen megnehezítik az összehasonlítást. Vizsgálódásom alapját az egyes tantervek illetve tanulmányi szabályzatok, helyi tájékoztató kiadványok képezték. Fontos információkat szereztem a személyes látogatások során. Az oktatási programok összehasonlító elemzése mellett lényegesnek tekintem az általános müködési feltételek értékelését.

\section{Az általános múködési feltételek.}

1. A berlini iskolát a „Képzési, oktatási és tudományos” minisztérium tartja fenn, azaz polgári tanintézet, melyen belül egy rendvédelmi fakultás müködik „Rendőrség és biztonsági management” megnevezéssel. A belügyminisztérium a hallgatók után fejpénzt fizet a müködéshez.

A másik három iskola közvetlenül belügyminiszteri alárendeltségben, a minisztérium költségvetésén belül található. Az adott országok rendőrségeivel kiérlelt sokoldalú kapcsolatokkal rendelkeznek, de mindenhol a minisztériumi szervezetek azok, amelyek a szakmai elvárásokat közvetítik és a megvalósulást kontrolálják.

2. Fontos a hallgatók jogállásának értékelése. Berlin kivételével mindenhol polgári, az ország egyéb főiskolai hallgatóinak megfelelő jogviszonyban találhatók a tanulmányokat folytatók. A polgári hallgató nem rendőr, intézkedést nem foganatosíthat, egyenruhát nem visel. Kötelezettségei és büntethetősége az átlag állampolgárnak felel meg. Budapesten a hallgatók formaruhát viselnek, a másik két intézményben civilben folyik a képzés. Általában a tanulmányok befejezését követően kerülnek hivatásos állományba. Pozsonyban a második tanévet követően a legjobb eredményt elértek korlátozott számban kérhetik felvételüket a hivatásosok sorába. A hallgatók diákszálláson laknak, jelentősebb kötöttségek és szigorú napirend nélkül. Szabad mozgásuk kiterjed a teljes oktatásmentes délutánra, valamint az éjszakára. Nagyvonalú szabályozás jellemzi az óralátogatási kötelezettséget, Prágában nem is elöírás. Az általános napirendből jobbára hiányoznak a katonai képzési intézményekre jellemző összetartási-ellenőrzési munkaformák, alaki képzések (egyedül a magyarnál található), a kötelékgyakorlatok. Berlinben a hallgatók a tanulmányok megkezdésekor hivatásos állományba kerülnek a nálunk nem létező „visszahívható tisztviselő” megnevezéssel. Ez a kategória lényegében egész Németországban megtalálható és a rendvédelmi képzést végző intézmények hallgatóinál is alkalmazzák. Tanulmányaik ideje alatt az érintettek részben egyenruhát viselnek és korlátozott rendőri feladatokat oldhatnak meg. Természetesen anyagi elismertségük is ennek megfelelö, havi ezer euró ösztöndíj. Ez az iskola nem tart fenn diákszállót, hallgatói a városban önállóan bérelnek lakást. Erre egyébként a többi iskolánál is lehetőség van, a bentlakás nem kötelező, csak esetleg anyagilag kifizetődőbb. Németországban viszont „,polgár közeli rendőrség” címszóval egyes tartományok, így Berlin is, nem támogatja a rendőr növendékek egységes, szervezett elhelyezését, mondván, éljenek a lakosság között, tegyenek szert ezáltal is polgárbarát tapasztalatokra. Magyarországon a hallgatókkal a rendőrség a tanulmányok kezdetekor szerződést köt, melyben vállalja, hogy a hallgatót a föiskola eredményes befejezését követően valamilyen munkakörben, hivatásos vagy közalkalmazotti, köztisztviselői státuszban, foglalkoztatni fogja. Prágában és Pozsonyban ilyen biztosíték nincs, mindenki a végzéskor tudja meg, rendőr lesz-e, vagy a szabad munkaerő piacon kell a helyét megtalálnia. 
3. Mind a négy intézmény akkreditált Bologna típusú bachelor képzést folytat, Berlinben még kifutó régi föiskolai képzéssel. A csatlakozás a bolognai rendszerhez a polgári felsőoktatás egyes szervezeti elemeit és követelményeit hozta be a korábban zártabb intézmények falai közé. Az országos felsőoktatásért felelős civil minisztériumok belépést nyertek a rendvédelmi képzési rendszerekbe, szervezeteik részt vesznek a minősítési eljárásokban, engedélyezési folyamatokban. Az oktatókkal szemben most már az adott állam felsőoktatási követelményei érvényesek, egyetemi végzettség, tudományos fokozatok, habilitáció, stb. jelent meg az elvárások között. Módosultak a régi típusú szakmai felkészítés személyi feltételei, nem elegendő jó szakembernek lenni ahhoz, hogy valaki fóállású oktató legyen. Ezzel kapcsolatban ne tévesszen meg senkit a két iskola, Pozsony és Prága által használt „akadémia” név, kifejezés. Mindkét intézmény egyetemi státuszú, master és doktori képzéssel. Németországban több tanintézet az akadémia kifejezéssel jelöli, hogy nincs a bolognai rendszerben akkreditálva.

A bolognai rendszer bevezetésével egy időben mind a négy tanintézet belépett az Európai Kreditátviteli Rendszerbe, (European Credit Transfer System, ECTS), és az általuk müvelt tananyagot átszámították a kötelező 180 kreditpontra, csatlakozva az Európai Felsőoktatási Térséghez. Valamilyen mértékben igyekeztek megfelelni az újonnan jelentkezett tantárgy és képzési szerkezeteknek, a kötelező- kötelezően és szabadon választható blokkok kialakításának. Ezen a téren véleményem szerint a prágai megoldás jutott el a legrugalmasabb megoldás kialakításához, ahol 175 kreditpont megszerzéséhez (5 pont a szakdolgozat), összesen 75 tantárgy 361 kreditjéből a hallgató részben maga alakítja ki a saját felkészülési rendszerét, természetesen a Tanulmányi Osztállyal konzultálva. Mindenképpen figyelemre méltó, hogy összesen csak 12 kötelezö, megkerülhetetlen tantárgy van, melyek 101-103 kreditpontot biztosítanak a tanulmányok során. Ezek teljesítése mellett 63 tantárgyból válogathat a résztvevő a további 72 kreditpontért. $^{7}$

4. Új kihívásként jelentkezett az Európai Unió által beindított „Erasmus” képzési-pályázati rendszer, mely uniós költségvetésböl hallgatók külföldi tanulmányait és szakmai gyakorlatát, valamint oktatók külföldi hospitációját finanszírozza. A három- négy hónapos távolléttel járó tanulmányutak megvalósítása, lehetővé tétele érdekében az iskolák rugalmasan átalakították tanulmányi követelményeiket. A civil felsőoktatásból olyan megoldásokat vettek át, mint vizsgahalasztás, vizsgák csúsztatása, külföldön szerzett kreditpontok elismerése, külföldi hallgatók fogadása, angol nyelvü szakmai oktatás felkínálása, szorgalmi időszak későbbi elkezdése vagy korábbi lezárása, stb.. Mind a négy iskola tagja az Erasmus rendszernek és a jelentkezőket elsősorban angol, német és francia nyelvterületre küldik. A lehetőségeket a legnagyobb hallgatói számban, kb. 30 fó/év talán a budapesti Rendőrtiszti Főiskola használta ki leginkább.

5. A rendvédelmi felkészítésben bekövetkezett fontos változásnak tekintem a nők fokozott megjelenését a rendvédelem és az ehhez kapcsolódó felkészítés területén. Számuk fokozatosan emelkedett a jelentkezők és a tanintézetekben végzők körében egyaránt. A németországi helyzet még szembetünőbb ezen a téren, amennyiben ők ebben a folyamatban előrébb állnak. Személyzeti döntést - felvételi, előresorolás, stb. - csak bizottságilag lehet meghozni, mely grémiumnak egyik tagja, ha a mérlegelés hölggyel kapcsolatos, a női egyenjogúsági megbízott, a szervezet egyik női munkatársa. Ma a négy tanintézetben a női hallgatók aránya átlagosan 30\% körül mozog, akik nem csak az igazgatásrendészet, de valamennyi szolgálati ág iránt érdeklődnek. Berlinben a 182 rendőr hallgatóból 42 hölgy, 23\%. Ha a polgári biztonsági képzéssel együtt vizsgáljuk a kar 625 hallgatójából 438 hölgy, 70\%. Brandenburg Tartomány rendőrtiszti főiskolájára 2006-2010 között felvett hallgatók esetében a hölgyek aránya évente 34\%,25\%, 37\%, 31\%, 21\% volt, (Lásd I.,II.,II.sz. mellékletek).

\section{A tantárgyszerkezetek elemzése.}

A tantárgyszerkezetek értékelését azért tekintem fontosnak, mert ezen keresztül ítélhető meg az, hogy milyen jellegü munkára készítik fel a hallgatókat, körülbelül milyen típusú az a szervezet ahol dolgozni fognak. A tantervek, képzési programok — talán némileg önhatalmúan — három fö csoportra bontják a tantárgyakat, úgymint jogtudományi, általános ismereti és szakmai. A föiskolai szintű képzés és a művelt állampolgárral szemben támasztott elvárás természetesen nem nélkülözheti az általános ismereti tudásanyagok feldolgozását, rendvédelmi jellegü megközelítéssel. A vezetéselméleti és testnevelési (fizikai, önvédelmi) ismereteket, kiképzést a szakmai felkészítés rubrikájába számoltam. (Lásd IV.sz. melléklet). Ez a besorolás jellemző az általam megismert intézményekre. 
A jogtudományi tantárgyak képezik a rendvédelmi felsőoktatási képzés egyik alapvető tantárgycsoportját. Nyugat- Európában ezek belső tartalmában is jelentős közeledés figyelhetö meg, amennyiben az európai uniós jogszabályok feldolgozása tipikus és belső tartalmukban hasonló, illetve azonos. Az idegenrendészeti jog, a menekültügy, az uniós vámszabályok, a rendőrség nemzetközi együttmüködésének jogi alapjai, a nemzetközi jogi ismeretek nagymértékben megegyeznek. A hazai belső jogban is az egyes államok között sok a hasonló vonás, azonos elméleti megközelítés. A budapesti Rendőrtiszti Főiskolán a jogtudományi tantárgyak aránya 20,78\%, összesen 532 tanóra. Kreditértékre számolva a hét jogi tantárgy összesen 49 kreditet a kötelező 180 kreditpont 27\%-át teszi ki. Hadijogi témák lényegében nem szerepelnek az oktatásban.

A prágai rendőr akadémián két tantárgycsoportba besorolva található a jogtudományi tárgyak zöme és ezekből minimum 52 kreditpont megszerzése a kötelező, ez az elöírtak 29\%-a. Szabadon választásos alapon a hallgatók még további 6 kreditpontot szerezhetnek három másik jogi tárgy felvételével.

Szlovákiában az összóraszám a hat szemeszter alatt 2152 tanóra, a jogtudományi tantárgyak óraszáma 776 óra, azaz az összes óramennyiség 36\%-a. ${ }^{8}$

Berlinben rendkívül magas az összóraszám, melyet a szorgalmi időszakon kívül tartott 24 hét szakmai gyakorlat emel meg. Ezzel együtt az óraszám 3336 melyből 558 tanóra a jogtudományi tantárgy, amely az összóraszám 17\%-a és ezekre az órákra 29,5 kredit kapható, amely az összkreditérték 16\%-a. A berlini tanintézet az egyetlen a négy föiskola közül, ahol az ismeretanyag feldolgozása modulrendszerben történik, az óra és kreditszámok nem tantárgyakra, hanem modulokra vannak kiszámolva, ez természetesen részben nehezíti az összehasonlítást. A vizsgáztatás és számonkérés is az egyes modulok befejezésekor történik, esetenként egy időben több tantárgy anyagából, melyek az adott tanulmányi egység részeit képezték. Így viszont nincs vizsgaidőszak, több hetet megtakarítanak a másik három intézményhez képest. ${ }^{9}$ (Lásd V.,VI., VII.sz.melléklet)

A szakmai ismereteket közvetitö tantárgyak a tanintézetekben azonosak, esetleg apró névmódosítással különböznek. Lényegében rendvédelmi jellegü tárgyakról van szó, mint kriminológia, kriminalisztika, bünügyi ismeretek, vezetéselmélet, fizikai és önvédelmi felkészítés.

Magyarország szakirányokra bontja a rendőri felkészítést. Így nálunk létezik bünügyi nyomozó, gazdaságvédelmi nyomozó, határrendészeti, igazgatásrendészeti, közlekedésrendészeti, közrendvédelmi szakirány. Budapesten a legszélesebb a skála. Berlinben bűnügyi és közrendvédelmi, Pozsonyban bünügyi, vizsgálati, közrendvédelmi, határ és idegenrendészeti szakirányok (specializációk) müködnek. A hamburgi rendőrtiszti főiskolán található kimondottan vízirendőrségi szakirány. Alapítását minden bizonnyal a hamburgi tengeri kikötő, Európa harmadik legnagyobb ilyen jellegü létesítménye, az óriási konténeres terminál és a nagy tengerjáró hajókat is fogadó elbai vízi út ellenőrzése indokolja. Önálló gazdaságvédelmi, igazgatásrendészeti és közlekedésrendészeti szakirány egyedül Magyarországon található a négy iskola közül.

A szakok, szakirányok, specializációk mindenütt közös és eltérő tananyagrészekkel rendelkeznek, elválasztásuk iskolánként eltérö. Nálunk Budapesten ez relatíve gyorsan, már az első szemeszterben megtörténik.

Pozsonyban jelentősen eltér a hazai megoldástól, hogy a szakirányok tananyaga az első három félévben szinte megegyezik, a csekély eltérést hét választható tantárgy képezi, melyek közül három kötelező. A 828 órás teljes képzési időből e tárgyak tanóramennyisége 72 óra. A negyedik szemeszter 324 órájából 72 kötelezően (alternatív) és 24 szabadon (fakultatív) választható. Az ötödik szemeszterrel bontakoznak ki a specializációk és a szakirányok, összesen 216 órában a tanulmányok végéig, melyből 144 óra a kötelezően (alternatív) és 72 óra a szabadon (fakultatív) választható. ${ }^{10}$

Berlinben a modulok segítségével választják el a szakirányokat amennyiben vannak közös blokkok. A bünügynek három, a közbiztonságnak négy modulja van, illetve eltérő a szakmai gyakorlatok rendszere is.

Törekvés látható a képzési programokon belül a rendőrségi szolgálati ágak ismeretanyagának leképezésére. A készenléti rendőrségi tevékenységek, a csapatvezetés, kötelékek irányítása témakör önálló modulban markánsan Berlinben jelenik meg.

A sport, önvédelem mindenütt szerepel a tematikákban, tipikus a heti 2 tanóra, mely meglehetösen kevésnek tủnik, de valószínüleg ennyi fér az oktatási programokba. A rendőri jellegü önvédelem a konfliktus megelőzésére irányul, lefogást, elvezetést alkalmaz. Kerüli a sérülés okozását, eszköze a rendőrbot. Teljesen hiányzik a katonai küzdősportokra jellemző kés használata, valamint löfegyver ütésre alkalmazása, a konfliktus támadó jellegü kezdeményezése, a megsebesítésre törekvés. Egyes iskolákon úszás és vízből mentés oktatás is folyik, itt követelmény az erre vonatkozó ta- 
núsítvány megszerzése. A hallgatók körében mindenütt népszerüek a különböző küzdősportok és közelharc fajták fakultatív sportkörökben történő oktatása, nem a tananyag részeként. Fontosak a különböző sportszakosztályok, egészen különlegesek is találhatók (hegymászás), valamint lövész szakosztály, klub, mely kiegészíti az általában szerény fegyverhasználati felkészítést.

Löfegyverismeretet és lövészetet természetszerüen a rendőrségi igényeknek megfelelöen oktatnak, melyet a rendszeresített eszközökkel valósítanak meg. Esetenként csak pisztoly szerepel a kiképzésben. Valószínüleg Budapest dolgozik a legszélesebb skálán, ahol gépkarabély használatot, tájékoztató jelleggel vadászpuskát is bemutatnak. A rendvédelmi jellegre jellemzően kis távolságból (6-8 méter), speciális körülmények közötti (utca, nyilvános hely, stb.), önvédelmi célú fegyverhasználati gyakorlás folyik egyre inkább számítógépes vezérlésű belső lötereken. A lőfegyverhasználat filozófiája homlokegyenest eltér a katonaság nagyobb távolságra irányuló, a menekülő személyt sem kímélö megoldásaitól.

A gépjármüvezetésnél alapelvárás valamennyi vizsgált országban a „, $\mathrm{B}$ kategóriás vezetői engedély megléte. Nem törekednek, mint a honvédség, a „C" típusú jogosítvány meglétére, mivel nincs szükség és alkalom nehézgépek vezetésére. A brandenburgi iskola kivételével a speciális rendőrségi felkészítés részét képező vezetési ismeretek, azaz a bonyolult forgalomban való közlekedés, a gépjármüvek üldözéséhez szükséges ismeretek megszerzése, költségességük és jelentős eszközigényük miatt egyik tanintézet programjában sem szerepel. Brandenburgban valószínúleg azért képezi a tisztképzés részét ezen tananyag, mivel a tiszthelyettesek hasonló jellegü felkészitését is itt végzik.

A szakmai gyakoroltatás terén jelentős ingadozás tapasztalható. A tanulmányok alatt a rendőrség egyes szervezeti egységeinél eltöltött idő széles skálán mozog. Prágában elméletileg nincs szakmai gyakorlat a három év alatt. Szerveznek látogatásokat, tanulmányi utakat. Vannak tantárgyakhoz kapcsolódó alkalmazói foglalkozások, pl. egy hét kriminalisztikai gyakorlat, összekovácsolási foglalkozások. A magyarázat abban rejlik, hogy a prágai akadémia az egyetlen képzési intézmény ahol a végzés után a hallgatókat a rendőrség — már hadnagyi rendfokozattal — egy év rendöri felkészítésben részesíti a rendészeti szakközépiskolában. Az iskolának nem kötelessége a hat szemeszter alatt teljesen kvalifikált tiszteket kibocsátani, azokra még a rendőrség „,rádolgozik”. Lényegében a tanintézetben folyó oktatás és a rendvédelmi testületben megvalósuló munka között gyakornoki időt alakítottak ki. Ezt figyelembe véve a prágai rendőrtiszti felkészítés összideje nem 3, hanem 4 évnek tekinthető. A pótlólagos felkészítés 9 hónap elméleti és 3 hónap gyakorlati időt jelent. Ennek megfelelően ök a föiskolai tanterveiket inkább elméleti jellegü, átfogóbb stílusban tervezhetik. Magyarországon a szakmai gyakorlat mintegy 400 órában a rendőri munka több színjét (járőr, nyomozó, kapitányság), bemutatja.

Berlinben a program a 16. modulban tanulmányi gyakorlat címén 42 hetet ír elö 57,5 kreditpont értékkel. Ennyire hosszú időt csak úgy tudnak teljesíteni, a képzési rendszerbe beépíteni, hogy az ötödik szemeszterben a hallgatók nincsenek az iskolában. Ez 18 hét, a többi 24 hetet pedig elosztják az egyéb félévek között és a szorgalmi időszak után (nincs vizsgaidőszak), kezdik a gyakorlatot. Ha viszont ennek a 42 hétnek a tartalmába belenézünk, láthatjuk, itt nem a klasszikus magyar értelemben vett föiskolai szakmai gyakorlatról van szó. Keverednek az oktatási, kiképzési tevékenységek és a rendőr kirendeltségeken eltöltött idők. Ennek oka vélhetően az, hogy a tanintézet polgári jellegünek tekinthető, amely a rendőri infrastruktúra jelenlétének a hiányát jelenti. Amit tehát a civil iskola nem tud biztosítani azt a testület különböző típusú szervezeti egységeinél, illetve tiszthelyettes iskolán valósítják meg. ${ }^{11}$

A kriminológia és a kriminalisztika a szakmai tantárgyak külön kiemelkedő csoportját képezi. Az utóbbinak jelentős labor, technikai és anyagigénye van. Ezen tárgyak alapozzák az általános és kiemelten a bünügyi területü felkészítést. Különösen kedvezö helyzetben van Pozsony, ahol a bünügyi-technikai intézet közvetlenül az iskola mellett található, de a többi föiskola is fóvárosban van, így támaszkodhatnak az ide koncentrálódott rendőrségi- igazságügyi létesítményekre. (Lásd VIII.sz. melléklet)

Az általános ismereti tantárgyak a rendörtiszt képzés fontos részét alkotják.

A nyelvoktatással valamennyi vizsgált tanintézet foglalkozik. Németország van a legkedvezőbb helyzetben, mint nagy létszámú nemzet (82 millió), tipikusan csak angol nyelvre készítik fel a hallgatóikat. Mivel az angol a nemzetközi rendőri együttmüködés és tevékenység nyelve, ez elegendőnek bizonyul. Németországban a középiskolákban az angol a kötelező első idegen nyelv, a föiskolára érkező hallgatók megbízható alapokkal indulnak a felkészitésben, melyben a tipikus rendőrségi szituációk feldolgozására fordítják a hangsúlyt. Elvárás a B1 európai nyelvvizsga, amit az érintettek többsége már a 
középiskolai tanulmányai során megszerzett. A másik három föiskola az angol mellett német, orosz és francia nyelvet is oktat. Az oktatott nyelvek valamelyikéből a képzés végére a hallgatóknak eredményes nyelvvizsgát kell tenniük. A nyelvi tanulmányokat kreditpontokkal is elismerik, Budapest 9 , Prága 10, Pozsony 7+6 (szabadon választott). (Lásd IX.sz. melléklet)

Álláspontom szerint a vizsgált tanintézetek helyzetéből több következtetés vonható le.

- Az általam megismert rendvédelmi iskolák bachelor képzésének tananyagaiból és az iskolák müködési filozófiájából, tevékenységükből hiányzik a militáns jelleg. A felsőoktatási tanintézetek irányába nyitó folyamat zajlik ezen országokban.

- Az európai uniós egységesülési folyamat kihat az Európai Unió tagállamainak a rendôrségeire is, ezen keresztül pedig a rendőri oktatásra. Ez nem csak a jogtudományi, hanem a szakmai területeket, tananyagokat is érinti.

- A „Bologna-i folyamatba” való belépéssel az iskolák müködési körülményei közelítenek a polgári felsőoktatási intézetekhez. Az Európai Felsőoktatási Térséghez tartozás potenciális lehetőségeket biztosít a rendör hallgatók nagyobb mértékủ időszakos külföldi képzésére, nem utolsó sorban annak anyagi fedezete biztosítására.

- A főiskolai szintü BA alapfelkészítés mellett megjelent az önálló rendvédelmi master (egyetemi), diploma iránti igény, ezzel is kiszolgálva a rendőrségek vezetői szükségletét. Mind a négy országban létezik akkreditált rendvédelmi egyetemi szak, a négy iskola közül Budapesten, Pozsonyban, Prágában. Németországban Münsterben a németországi rendőrségek által fenntartott felsőoktatási intézmény, amely Európa talán legjobban szervezett és finanszírozott, rendvédelmi jellegü, akkreditált, két éves, nappali tagozatos egyetemi diplomát biztosító tanintézete.

- Lehetőség nyílik doktori iskola alapítására is, alapozva a meglévő BA és MA szakokra. Kedvezőek a feltételek Ph.D. felkészítés akkreditálására, indítására. Doktori iskolával rendelkezik a prágai és a pozsonyi tanintézet. A Nemzeti Közszolgálati Egyetem 2012. I. 1.-i létrejöttével — mivel az egyetemen doktori iskola van - nálunk is pozitívak a kilátások. ${ }^{12}$

[Különös, hogy az egyetlen magyar nyelvủ és a magyar rendvédelem-történeti tartalmú tudományos igényü alkotások közlését fő feladatának tekintő tudományos periodikához a szerző a szakterületéről olyan írást küldött publikálásra, amelyben még csak említést sem tesz a hivatástörténet oktatásáról. A cikk jól példázza azt a sajátos szemléletet, amely a magyar rendvédelmi értelmiségképzés számára a hivatástörténeti oktatást elhanyagolhatónak tartja. Ezzel párhuzamosan pedig — egy kitüntetett prekoncepció érdekében - az egyik külföldi modell átvételét szorgalmazza. E favorizált modellt pedig a fejlödés egyetlen lehetséges útjaként igyekszik érzékeltetni. (A szerk.)]

\begin{abstract}
Jegyzetek:
${ }^{1}$ A rendörtisztek felkészítésének a tananyaga mindig is eltért a katonai tisztképzés tartalmától. Ebben nincsen új vonás. Magyarországon a polgári magyar állam időszakában is elkülönült a rendőrtiszti és a katonatiszti képzés. A rendőrség — a polgári magyar állam időszakának terminológiájával élve — polgári fegyveres őrtestületnek minősült, ennek megfelelő volt a rendőrtiszti képzés tartalma is. Lényegében jogtudományi képzettségre — tisztek esetében jogakadémiai oklevélre, kapitányságvezetők esetében pedig jogtudori oklevélre - épülő szakképzés alkotta a rendőr tisztképzést. Azonban a rendőrtiszt kifejezés is helytelen, mivel öket rendörtisztviselőknek nevezték. A XIX. és a XX. században is figyelemmel kísérték a leendő rendőrtisztek felkészítését megvalósító intézmények tevékenységét Európa jelentősebb országaiban és a hasznosítható tapasztalatokat igyekeztek adaptálni. Az új vonás az, hogy az Európai Unió néhány alaptételének a megvalósulása érdekében (személyek és áruk szabad mozgása) illetve a bünözés egyes fajtáinak nemzetközivé válása miatt valamennyi tagországra kiterjedő érvényességü szabályozók születtek, amelyeket értelemszerủen a nemzeti rendvédelmi testületek hivatottak kivitelezni. A tagállamok által közösen kialakított rendvédelmi elvárások azonban nem tesznek különbséget a katonailag szervezett és a polgári fegyveres őrtestületek között. A rendvédelem érdekében azonban nem csupán rendőri testületeket müködtettek a polgári Magyarországon — mint ahogy napjainkban az Európai Unió több társországában hanem csendőrségeket is. A csendőrök pedig személyükben katonának minősültek, ezért — a rendvédelmi tartalmú felkészítésük mellett — katonai kiképzésben is részesültek. A testület belső függelmi viszonyai katonaiak voltak. A testület személyi állományára a katonákra vonatkozó általános elvárások is érvényesek voltak. E katonai jelleg hiányában aligha lett volna képes a szervezet a tábori csendőri feladatkör ellátására. A magyar csendőrség eredményei tekintetében nem maradt el a rendőrségtől, sőt túlszárnyalta azt, olyan eredményeket produkálva, amelyet azóta sem sikerült felülmúlnia a későbbi korok rendvédelmi testületeinek. A rendőrség és a csendőrség egyaránt a korabeli magyar polgári demokrácia szabályai szerint és elvárásainak megfelelően müködött. A két rendvédelmi szervezettípus tevékenységének jellege között — azonos típusú tevékenységek ellátása esetében — eltérés nem volt. (a szerk.) BORBÉLY - KAPY ; PARÁDI: A polgári magyar állam első központosított közbiztonsági szerve a Magyar Királyi Csendőrség. ; PARÁDI: Rendörtisztképzésünk hagyományai 167-1945. ; PARÁDI: Rendvédelmünk képzési és képesítési rendszere 1867-1945. ; PARÁDI: A magyar rendőrtisztképzés tradíciói 1867-1945. ; PARÁDI: A csendőrtisztképzés és a fizetési osztályokba sorolt állami alkalmazottak szakvizsgarendszere. ; REKTOR ; SzAKÁLY.

${ }^{2}$ Négy közép-európai tagállam rendőrtisztképző oktatási programjának az értékelése, megítélésünk szerint szük bázis ahhoz, hogy az Európai Unió egészére vonatkozó következtetés levonható legyen. Nem kellően megalapozott kijelentésnek tekinthető, hogy a polgárbarát jelleget csak a polgári fegyveres örségek (rendőrség típusú rendvédelmi szervezetek) képesek megvalósítani. Azokban az országokban, ahol katonailag szervezett örtestületek is müködnek (csendőrségek) ezt a kijelentést minden bizonnyal cáfolnák. (a szerk.)
\end{abstract}


${ }^{3}$ A rendőri testületek személyi állományába tartozók egy részénél a civil ruha viselete, illetve az, hogy a rendőri testületek személyi állományának egy része karhatalmi feladatok ellátására specializált szervezetben teljesít szolgálatot, amely szolgálati ág a müködése során nem tekinti ellenségnek az intézkedés alá vont tömeget nem új jelenség. Ez már megvalósult a polgári magyar állam időszakában is a XIX-XX. században a csendőrség és a rendőrség tekintetében egyaránt. A detektívek például nem is viselhettek egyenruhát stb. A szolgálati fellépés jellegében a hadi típusú módszerek mellőzése nem csupán a rendőri, hanem valamennyi rendvédelmi szervezet sajátja volt. Ellenkező esetben aligha lettek volna képesek kellő eredményességgel müködni, hiszen az Európai Unió jelenlegi nemzeti rendvédelmi testületeinek a második világháborút megelőző időszakban müködő elődszervezetei többségükben többé-kevésbé a polgári jogállam keretei között tevékenykedtek. (a szerk.)

VÉCSEY ; TÖRÖK - NÉMETHY

${ }^{4}$ Az új helyzetet kialakító szabályozások és intézmények:

- a Schengeni Egyezmény,

- a Schengeni Végrehajtási Egyezmény,

- a Dublini Menekültügyi Egyezmény, 1997- től hatályban,

- a Schengeni Információs Rendszer, SIS,

- a közös uniós vízumszabályozások,

- az ujjlenyomatok összehasonlítására irányuló „Eurodac” létrehozásáról szóló 2725/2000/EK rendelet,

- Eurojust információs rendszer, 2002,

- az államhatáron átnyúló üldözés megjelenése a gyakorlati munkában, az ezt lehetővé tevő kétoldalú nemzetközi szerződések,

- az európai elfogató parancs szabályozásának hatályba lépése,

- nemzetközi jogsegély szolgáltatás,

- Európai Rendőrségi Hivatal, (EUROPOL),

- Európai Rendőr Akadémia, (CEPOL).

${ }^{5}$ Azzal a tartalommal, amit Magyarországon napjainkban a „rendészettudomány” tartalmaként a terminológia védelmezői megfogalmaznak, nem lehet komolyan venni ezt a „szakterületet”, mivel ez áltudomány. Az úgynevezett „rendészettudomány” által lefedett terrénumokat ugyanis már más tudományok uralják. E tudományok egyes ágait valóban a rend védelme érdekében művelik, például kriminálszociológia, kriminálpedagógia, krimiálpszichológia stb. Ezeket a résztudományokat azonban nem lehet egy tudománynak tekinteni, mivel nincsen közös metodikájuk, kizárólag az anyatudomány módszertanával művelhetők. Önálló tudományterület és metodika hiányával tehát áltudományként kezelhető a „rendészettudomány" a jelenlegi tartalmával. Ezen a tényen az sem változtat, ha a hatalmi csoportosulások között lavírozók időlegesen érvényt szereznek téveszméiknek, illetve a hivatásukat szeretőket sikerül félrevezetniük hangzatos szólamokkal. Azok a híresztelések, amelyek szerint a szlovén és a szlovák tudományos akadémiák elfogadták a „rendészettudományt” önálló tudományként — amennyiben a hírek igazak — elsősorban e nemzetek rendvédelmi lobbijainak érdekérvényesítő képességét bizonyítják, nem pedig e két nemzeti tudományos akadémia működésének a kiforrottságát. Az sem felel meg a valóságnak, hogy Németországban a ,rendészettudomány” polgárjogot nyert volna, mivel a polizeiwissenschaften kifejezés nem rendőrtudományt, hanem rendőrtudományokat jelöl, amely nem jelent más mint a rendvédelem érdekében müvelt tudományágak gyüjtőelnevezése, de koránt sem egy önálló tudomány jelölése. (a szerk.)

${ }^{6}$ A közép-európai nemzeti rendvédelmi rendszerek változásait nem lehet egy homogén folyamatnak tekinteni. Abból a szempontból ugyan valóban egy tőről fakadnak, hogy a második világháborúban gyökerezik a változás. Nevezetesen a második világháború után a szovjet hadsereg által megszállt területen az orosz indíttatású szovjet rendvédelmi mintát vezették be, a vesztes Németország nyugati felére pedig az USA rendvédelmi modelljét adaptálták. A volt Varsói Szerződés tagállamaiban az orosz-szovjet modellt valamilyen módon lebontották. Németország mozgásterét azonban behatárolja az a félsz, hogy a rendvédelmi struktúrája még véletlenül se hasonlítson a harmadik német birodalom rendvédelmi szerkezetére. Ezért nyilvánvalóan nem mer visszatérni a hagyományaihoz, ́gy a két német állam egyesülése után a volt keletnémet területeken is az ameriaki adaptált mintát vezették be. Egyébként pedig — mivel az adaptált amerikai modellt a németek már „,belakták” az jól szolgálja a biztonságukat, ezért — lényeges változtatásokra nem is törekszenek. A Varsói Szerződés volt tagállamainak a helyzete a némettől eltérő, mivel a térség nemzetei jogosan térhetnek vissza a saját történelmi gyökereikhez, a nemzeti kultúrkörnyezetükben már bevált rendvédelmi modellekhez. A legtöbb országban ezt meg is tették. Így került sor például Romániában és Szerbiában a nemzeti csendőrségek reorganizálására.

Ennek a folyamatnak azonban semmi köze ahhoz, hogy milyen típusú függelmi viszonyrendszer szerint müködő testületek találhatók az egyes rendvédelmi modellekben. Nem azért választották az egyes nemzetek az egyik vagy a másik modellt, mert az tartalmazott vagy nélkülözött katonailag szervezett örtestületet.

Napjainkban az egyes országok rendvédelmi modelljének az alakítása lényegében egy tágabb vitatéma részét képezi. Nevezetesen a tét az, hogy milyen mértékben oldódjanak fel a nemzetállamok az Európai Unió által képviselt globalitásban. Ezt pedig nyilvánvalóan a nemzeti érdekek és az erőviszonyok határozzák meg. A polgári fegyveres örtestület kontra katonailag szervezett őrtestület vitája tehát lényegét tekintve álvita, mivel mindkét modell kitűnően megállja a helyét. Nyilvánvalóan a nemzeti hagyományoknak kellene e kérdést eldönteni. Mivel azonban a globalizáció hívei a polgári fegyveres őrtestület típusa mellett tették le a garast, a globalizációt és a nemzeteket előtérbe helyező álláspontok közötti csatatér egyik elméleti mellékhadszínterévé vált a téma. Ez a jelenség érdekes módon nem idegen a magyar rendvédelemtörténet számára, mivel hasonló viták zajlottak a reformkorral kezdődően a közigazgatás témakörének részeként a rendfenntartásról Magyarországon is. Abban az időben azonban a municipalisták ragaszkodtak a rendőrséghez és a centralisták támogatták a csendőrség gondolatát. A harmadik évezred elejére 180 fokos változás történt, mivel a központosítást támogató globalisták a rendőrség, míg a nemzeti önállóságot előnyben részesítők a rendőri és a csendőri típusú rendvédelmi testületeket is magába foglaló úgynevezett kontinentális rendvédelmi modell mellett törnek lándzsát. Természetesen e két irányzat csak a markáns irányvonalakt tükrözi, köztük számos köztes felfogás is napvilágot látott. (a szerk.) FORRÓ 
${ }^{7}$ A Cseh Köztársaság Rendőr Akadémiáján hallgatható kötelező tárgyak és azok kreditértéke:

Kötelező tárgyak, 101-103 kredit, 12 tantárgy:

- Idegen nyelv, $10 \mathrm{kr}$.,

- Kriminalisztika, 12 kr.,

- Kriminológia, 9-11 kr.,

- Vezetéselmélet, 6 kr.,

- Politológia, 4 kr.,

- Pszichológia, 11 kr.,

- Szociológia, 4 kr.,

- Közigazgatási jog, 11 kr.,

- Álam és jogelmélet, 11 kr.,

- Büntetőjog,11 kr.,

- Polgári jog alapjai, 6 kr.

- Gazdasági jog alapjai, 6 kr. (1)

NovOSAD - LuKESOVÁ - MUdROVÁ:

${ }^{8}$ Studijná prírucka, Akademicky rok 2010/2011.17 .p.

9 Studienführer Pol B.A. SS 2011. 6.p.

${ }^{10}$ Studijná prírucka, Akademicky rok 2010/2011. :.op.cit.. 18.p.

${ }^{11}$ A berlini rendőrtiszképző főiskola szakmai gyakorlata több részből áll:

- Bevetési tréning, 7 hét, elosztva a hat szemeszterre, benne lövészet; $68 X 90$ perces sportfoglalkozás, félévente 17 az 1-

4 szemeszterekben; fegyverismeret, járörszolgálati tananyag.

- Információs és kommunikációs technikák,2 hét.

- Magatartás tréning, 2 hét.

- Bevetési és vezetési tanfolyam, 6 hét, kötelékvezetés, tevékenység szervezése.

- Kirendeltségi gyakorlat, 21 hét, három szemeszterre elosztva.

- Válaszható gyakorlat, 3 hét külföldön vagy az ország bármely részén tetszőleges állami vagy civil rendvédelmi szervezetnél.

Studienführer Pol B.A. SS 2011. : op.cit. 12-13.p.

${ }^{12}$ Hallgatói Tájékoztató, 2009/2010. tanév.

\section{A jegyzetekben alkalmazott röviditések:}

\section{MONOGRÁFIÁK ÉS KISMONOGRÁFIÁK}

\begin{tabular}{|l|l|l|}
\hline BORBÉLY - KAPY & - & $\begin{array}{c}\text { BORBÉLY Zoltán — KAPY Rezsö: A 60 éves magyar rendörség. Budapest, } \\
\text { 1942, Halász Irodalmi és Könyvkiadó Vállalat. } 600 \text { p. }\end{array}$ \\
\hline REKTOR & - & $\begin{array}{c}\text { REKTOR Béla: A Magyar Királyi Csendörség oknyomozó története. Cleveland } \\
\text { Ohio USA, 1985, Árpád Könyvkiadó Vállalat. 552 p. USA ISBN 0-934214-01-8. }\end{array}$ \\
\hline SZAKÁLY & - & $\begin{array}{c}\text { SZAKÁLY Sándor: A magyar tábori csendörség története 1938-1945. Buda- } \\
\text { pest, 2000, Ister. } 173 \text { p. HU-ISBN } 9639243248 \text { Ö. }\end{array}$
\end{tabular}

\section{TANULMÁNYOK}

FORRÓ $\quad{ }^{-} \quad$ FORRÓ János: Milyen legyen a jövő rendörsége? Rendvédelem-történeti Füzetek (Acta Historiae Preasidii Ordinis), XIX. évf. (2010) 22.sz. 30-45.p. HU-ISSN 1216-6774. A tanulmány korábbi változata 2008. október 10.-én Budapesten hangzott el a Szemere Bertalan Magyar Rendvédelem-történeti Tudományos Társaság által szervezett rendvédelem-történeti tudományos konferenciasorozatnak a „Másfél évszázad rendszerváltozásainak hatásai a nemzeti rendvédelmünkre." címü XXII. konferenciáján. A publikált tanulmány az előadás javított, bővített és átdolgozott változata.

PARÁDI: A polgári magyar állam első központosított, közbiztonsági szervezete a Magyar Királyi Csendőrség.

PARÁDI: Rendőrtisztképzésünk hagyományai 1867-1945 és képesítési rendszere 1867-1945.
PARÁDI József: A polgári magyar állam első központosított, közbiztonsági szervezete a Magyar Királyi Csendőrség. Belügyi Szemle, XXXVII.évf. (1989) 2.sz. 35-40.p. HU-ISSN 0133-6738.

PARÁDI József: Rendőrtisztképzésünk hagyományai 1867-1945. In DÁNOS Valér (szerk.): A rendörképzés reformja a kelet-európai változások tükrében. Budapest, 1991, BM Rendészeti Kutatóintézet. /Tanulmányok a rendészet köréböl, 1./ A tanulmány korábbi változata 1991. november 13.-án Balatonföldváron hangzott el. A Rendőrtiszti Főiskola által szervezett rendvédelmi szakképzési konferencián. A publikált tanulmány javított, bővített és átdolgozott változata.

PARÁDI József: Rendvédelmünk képzési és képesítési rendszere 1867-1945. Rendvédelem-történeti Füzetek (Acta Historiae Preasidii Ordinis), XIII. évf. (2007) 16.sz. 90-93.p. HU-ISSN 1216-6774. A tanulmány korábbi változata 2002. november 12.-én Budapesten hangzott el a Szemere Bertalan Magyar Rendvédelem-történeti Tudományos Társaság által szervezett rendvédelemtörténeti tudományos konferenciasorozatnak a „A rendvédelmi szakképzés története." címü XVI. konferenciáján. A publikált tanulmány az előadás javított, bővített és átdolgozott változata. 


\begin{tabular}{|c|c|c|}
\hline $\begin{array}{l}\text { PARÁDI: A magyar rendőrtisztképzés } \\
\text { tradíciói } 1867-1945\end{array}$ & & $\begin{array}{l}\text { PARÁDI József: A magyar rendörtisztképzés tradíciói 1867-1945. Rend- } \\
\text { védelem-történeti Füzetek (Acta Historiae Preasidii Ordinis), XIII. évf. } \\
\text { (2007) 16.sz. 94-99.p. HU-ISSN 1216-6774. A tanulmány korábbi változa- } \\
\text { ta 2002. november 12.-én Budapesten hangzott el a Szemere Bertalan Ma- } \\
\text { gyar Rendvédelem-történeti Tudományos Társaság által szervezett rendvé- } \\
\text { delem-történeti tudományos konferenciasorozatnak a ,,A rendvédelmi szak- } \\
\text { képzés története.” címü XVI. konferenciáján. A publikált tanulmány az } \\
\text { elöadás javított, bővített és átdolgozott változata. }\end{array}$ \\
\hline $\begin{array}{l}\text { PARÁDI: A csendőrtisztképzés és a fi- } \\
\text { zetési osztályokba sorolt állami al- } \\
\text { kalmazottak szakvizsgarendszere. }\end{array}$ & & $\begin{array}{l}\text { PARÁDI József: A csendőrtisztképzés és a fizetési osztályokba sorolt ál- } \\
\text { lami alkalmazottak szakvizsgarendszere. Rendvédelem-történeti Füzetek } \\
\text { (Acta Historiae Preasidii Ordinis), XIII. évf. (2007) 16.sz. 100-104.p. } \\
\text { HU-ISSN 1216-6774. A tanulmány korábbi változata 2002. november 12.- } \\
\text { én Budapesten hangzott el a Szemere Bertalan Magyar Rendvédelem- } \\
\text { történeti Tudományos Társaság által szervezett rendvédelem-történeti tu-, } \\
\text { dományos konferenciasorozatnak a ,A rendvédelmi szakképzés története." } \\
\text { címü XVI. konferenciáján. A publikált tanulmány az elöadás javított, bőví- } \\
\text { tett és átdolgozott változata. }\end{array}$ \\
\hline \multicolumn{3}{|l|}{ JOGSZABÁLY- éS ADATTÁRAK } \\
\hline TÖRÖK — NÉMETHY & & $\begin{array}{l}\text { TÖRÖK Lajos — NÉMETHY Tihamér (szerk.): Rendöri vonatkozású törvé- } \\
\text { nyek, rendeletek és eljárási szabályok gyüjteménye. Budapest, 1926, Editor. } \\
822 \text { p. /Rendőrtisztviselök Zsebkönyvtára./ }\end{array}$ \\
\hline VÉCSEY & & $\begin{array}{l}\text { VÉCSEY Leo et al. (szerk.): A negyven éves budapesti detektívtestület ju- } \\
\text { bileumi albuma 1886-1926. Budapest, 1926, Magyar Királyi Állami Rend- } \\
\text { örség Detektívtestületének nyugdíjpótló és segélyező egyesülete. }\end{array}$ \\
\hline \multicolumn{3}{|l|}{ TANTERVEK éS TÁJÉKOZTATÓK } \\
\hline $\begin{array}{l}\text { Hallgatói Tájékoztató, 2009/2010. } \\
\text { tanév. }\end{array}$ & & $\begin{array}{l}\text { Hallgatói Tájékoztató, 2009/2010. tanév. Budapest, 2009, Rendőrtiszti Föis- } \\
\text { kola. }\end{array}$ \\
\hline $\begin{array}{lll}\text { NOVOSAD } & \text {-LUKESOVÁ } \\
\text { MUDROVÁ: } & \end{array}$ & & $\begin{array}{l}\text { Karel NovOSAD — Dana LUKESOVÁ — Helena MuDROVÁ: Informace o } \\
\text { studiu akademicky rok 2010/2011. [A 2010/2011 tanév tanulmányi tájékoztató- } \\
\text { ja.] Praha, 2010, Policejní akademie České republiky. CZ ISBN 978-80-7251- } \\
\text { 330-7. }\end{array}$ \\
\hline $\begin{array}{l}\text { Studijná prírucka, Akademicky rok } \\
\text { 2010/2011. }\end{array}$ & & $\begin{array}{l}\text { Studijná prírucka, Akademicky rok 2010/2011. [A 2010/2011. akadémiai } \\
\text { év tanulmányi szabályzata.] Bratislava, 2010, Slovenská policie akademie } \\
\text { deska. SK ISBN - }\end{array}$ \\
\hline Studienführer Pol B.A. SS 2011. & & $\begin{array}{l}\text { Studienführer Pol B.A. SS 2011. [A rendör bachelor képzés 2011. évi } \\
\text { hallgatói tájékoztatója.] Berlin, 2011, Hochschule für Wirtschaft und Recht } \\
\text { Berlin. }\end{array}$ \\
\hline
\end{tabular}

Mellékletek jegyzéke:

I. sz. melléklet

A rendvédelmi hallgatók létszáma a berlini föiskolán 2010-ben.

II. sz. melléklet

Jelentkezés Főiskolai képzésre a Német Szövetségi Köztársaság Brandenburg tartományának rendőrtiszti föiskolájára. III.- sz. melléklet

A hölgyek aránya a budapesti Rendőrtiszti Főiskola a rendőri szakirányainak nappali képzésében a 2009/2010. tanévben. IV. sz. melléklet

Tantárgycsoportok a budapesti Rendőrtiszti Főiskola bűnügyi szakirány oktatásában. V. sz. melléklet

Tantárgycsoportosítás a budapesti Rendőrtiszti Főiskola bünügyi szakirányának nappali képzésén.

VI. sz. melléklet

A jogtudományi tantárgyak aránya.

VII. sz. melléklet

Tantárgycsoportok a föiskolákon tanórákban.

VIII. sz. melléklet

Kriminológia és kriminalisztika tantárgyak óraszáma és kreditértéke.

IX.sz. melléklet

Válogatott dokumentumok a vizsgált oktatási intézmények tanulmányi szabályzatai, tantervei, tájékoztatói közül. 
A rendvédelmi hallgatók létszáma a berlini föiskolán 2010-ben.

\begin{tabular}{|c|c|c|c|c|}
\hline Hallgató összesen & Férfi & Nö & \multicolumn{2}{|c|}{ Külföldi (nő és férfi) } \\
\hline 1063 honi +8 külföldi $=1071$ & 625 & 4338 & 8 & \\
\hline Szak szerint & Férfi & Nő & Ö̈sszesen & Külföld \\
\hline Kifutó föiskolai r. & 111 & 43 & 154 & 7 \\
\hline BA rendör & 71 & 50 & 121 & 0 \\
\hline BA biztonsági & 443 & 345 & 788 & 1 \\
\hline
\end{tabular}

Forrás?

II.sz. melléklet

Jelentkezés Föiskolai képzésre a Német Szövetségi Köztársaság Brandenburg tartományának rendörtiszti föiskolájára.

\begin{tabular}{|c|c|c|c|c|}
\hline \multirow[t]{2}{*}{ Év } & \multirow[t]{2}{*}{ Jelentkezők száma } & \multicolumn{3}{|c|}{ Felvettek száma } \\
\hline & & Férfi & Nő & összesen \\
\hline 1991 & 425 & 42 & 8 & 50 \\
\hline 1992 & 16 & 10 & 1 & 11 \\
\hline 1993 & 659 & 82 & 56 & 138 \\
\hline 1994 & 536 & 138 & 60 & 198 \\
\hline 1995 & 1073 & 89 & 61 & 150 \\
\hline 1996 & 991 & 84 & 66 & 150 \\
\hline 1997 & 1130 & 83 & 78 & 161 \\
\hline 1998 & 1826 & 98 & 52 & 150 \\
\hline 1999 & 1571 & 61 & 39 & 100 \\
\hline 2000 & 2416 & 78 & 26 & 104 \\
\hline 2001 & 1655 & 55 & 45 & 100 \\
\hline 2002 & 1615 & 56 & 44 & 100 \\
\hline 2003 & 1491 & 60 & 35 & 95 \\
\hline 2004 & 2550 & 71 & 29 & 100 \\
\hline 2005 & 2960 & - & - & - \\
\hline 2006 & - & 36 & 19 & 55 \\
\hline 2007 & 3011 & 71 & 24 & 95 \\
\hline 2008 & 2472 & 63 & 37 & 100 \\
\hline 2009 & 2340 & 69 & 32 & 101 \\
\hline 2010 & 2066 & 40 & 11 & 51 \\
\hline 2011 & 2539 & & & 100 \\
\hline összesen & 333342 & 1286 & 723 & 2009 \\
\hline
\end{tabular}

Forrás?

III. sz. melléklet

A hölgyek aránya a budapesti Rendörtiszti Föiskola a rendöri szakirányainak nappali képzésében a 2009/2010. tanévben

\begin{tabular}{||c||c|c|c||}
\hline Évfolyam & Férfi & Nö & összesen \\
\hline \hline I.évfolyam & 72 fö & $34,32 \%$ & 106 fö \\
\hline II.évfolyam & 54 fö & $30,35 \%$ & 84 fö \\
\hline III.évfolyam & 53 fö & $45,45 \%$ & 98 fö \\
\hline \hline összesen & $\mathbf{1 7 9}$ fö & $\mathbf{1 0 9 , 3 7 \%}$ & $\mathbf{2 8 8}$ fö \\
\hline
\end{tabular}

Forrás? 
Tantárgycsoportok a budapesti Rendörtiszti Föiskola bünügyi szakirány oktatásában.

IV. sz. melléklet,

\begin{tabular}{|c|c|c|c|c|c|}
\hline \multicolumn{2}{|c|}{ Jogtudományi ismereti tantárgycsoport } & \multicolumn{2}{|c|}{ Általános ismereti tantárgycsoport } & \multicolumn{2}{|c|}{ Szakmai ismereti tantárgycsoport } \\
\hline Büntetőeljárás jog & $\begin{array}{l}84 \text { tanóra } \\
8 \mathrm{kr} \text {. }\end{array}$ & Pedagógia & 28 tanóra & " Vezetés elm. & 42 tanóra \\
\hline Büntetőjog & $168,14 \mathrm{kr}$. & Pszichológia & $70,8 \mathrm{kr}$. & Kriminalisztika & 336 \\
\hline Közigazgatási jog & $84,8 \mathrm{kr}$. & Számítástechnika & $70,5 \mathrm{kr}$. & Kriminológia & 70 \\
\hline Polgári jog & $28,3 \mathrm{kr}$. & Etika & $28,3 \mathrm{kr}$. & Testnevelés & 140 \\
\hline $\begin{array}{l}\text { Nemzetközi } \\
\text { és eu. jog }\end{array}$ & $56,6 \mathrm{kr}$. & Politológia & $28,3 \mathrm{kr}$. & Intézkedéstaktika & 126 \\
\hline $\begin{array}{l}\text { Bevezetés } \\
\text { a jogtudományba }\end{array}$ & $\begin{array}{l}28 \\
3 \mathrm{kr} \text {. }\end{array}$ & Szociológia & $28,3 \mathrm{kr}$. & Bünügyi szolg. & 182 \\
\hline \multirow[t]{6}{*}{$\begin{array}{l}\text { Magyar } \\
\text { alkotmányjog }\end{array}$} & $84,7 \mathrm{kr}$. & Közgazdaságtan & $14,1 \mathrm{kr}$. & Gazdaságvédelem & 56 \\
\hline & & Idegen nyelv & $210,9 \mathrm{kr}$. & Igazgatásrendészet & 28 \\
\hline & & Kommunikáció & $28,2 \mathrm{kr}$. & Határrendészet & 28 \\
\hline & & & & $\begin{array}{l}\text { Közlekedés, köz- } \\
\text { rendvédelem }\end{array}$ & 28 \\
\hline & & & & Egyebek & 98 \\
\hline & & & & Szakmai gyakorlat & 390 \\
\hline Összesen & $\begin{array}{l}532 \text { tanóra, } 21 \% \\
49 \text { kr., } 27 \%\end{array}$ & & $\begin{array}{l}504 \text { tanóra } 20 \% \\
34 \mathrm{kr} .19 \%\end{array}$ & & $\begin{array}{l}1524 \text { tanóra } \\
59 \% \\
97 \mathrm{kr} .54 \%\end{array}$ \\
\hline Mindösszesen & & & 2560 óra és $180 \mathrm{kr}$ & & \\
\hline
\end{tabular}

Forrás?

V.sz. melléklet

Tantárgycsoportositás a budapesti Rendörtiszti Föiskola bünügyi szakirányának nappali képzésén.

\begin{tabular}{||l||c|c||c|c||}
\hline \multicolumn{1}{|c|}{ Tantárgyak } & Óraszám & Százalék & Kreditszám & Százalék \\
\hline \hline Jogi & 532 & $21 \%$ & 49 & $27 \%$ \\
\hline Általános ismereti & 504 & $20 \%$ & 34 & $19 \%$ \\
\hline Szakmai & 1524 & $59 \%$ & 97 & $54 \%$ \\
\hline \hline Összesen & $\mathbf{2 5 6 0}$ & $\mathbf{1 0 0} \%$ & $\mathbf{1 8 0}$ & $\mathbf{1 0 0} \%$ \\
\hline
\end{tabular}

Forrás?

VI.sz. melléklet

\begin{tabular}{||l||c|c|c|c||}
\hline \multicolumn{1}{|c|}{} & Audapest jogtudományi tantárgyak aránya & Prága & 2152 \\
\hline \hline Össz óra & 2560 & Berlin & & 776 \\
\hline \hline Jogi órák & 532 & 3336 & & $36 \%$ \\
\hline Százalék & $21 \%$ & 558 & 52 & 61 \\
\hline \hline Kreditpont & 49 & $17 \%$ & $29 \%$ & $34 \%$ \\
\hline Százalék & $27 \%$ & $16 \%$ & & \\
\hline
\end{tabular}

Forrás?

Tantárgycsoportok a föiskolákon tanórákban

\begin{tabular}{|c|c|c|c|c|}
\hline & Budapest & Berlin & Prága & Pozsony \\
\hline Jogtudomány & 532 óra $=21 \%$ & 558 óra $=17 \%$ & $29 \%(*)$ & 776 óra $=36 \%$ \\
\hline $\begin{array}{l}\text { Általános } \\
\text { ismeretek }\end{array}$ & 504 óra $=20 \%$ & 304 óra $=9 \%$ & $16 \%(*)$ & 312 óra $=15 \%$ \\
\hline $\begin{array}{l}\text { Szakmai } \\
\text { ismeretek }\end{array}$ & 1524 óra $=59 \%$ & 2474 óra $=74 \%$ & $55 \%(*)$ & 1064 óra $=49 \%$ \\
\hline $\begin{array}{l}\text { Összesen } \\
\end{array}$ & 2560 óra $=100 \%$ & 3336 óra $=100 \%$ & $100 \%$ & 2152 óra $=100 \%$ \\
\hline
\end{tabular}

(*) Kreditpontok alapján 
Kriminológia és kriminalisztika tantárgyak óraszáma és kreditértéke

VIII. sz. melléklet:

\begin{tabular}{||l|c|c|c|c|}
\hline \multicolumn{1}{|c|}{ Tantárgyak } & Budapest & Pozsony & Berlin & Prága \\
\hline \hline Kriminalisztika & 336 óra $=17 \mathrm{kredit}$ & 168 óra $=14 \mathrm{kredit}$ & 398 óra $=27,5 \mathrm{kredit}$ & 300 óra $=22 \mathrm{kredit}$ \\
\hline Kriminológia & 70 óra $=5 \mathrm{kredit}$ & 48 óra $=4 \mathrm{kredit}$ & 173 óra $=10 \mathrm{kredit}$ & 75 óra $=11 \mathrm{kredit}$ \\
\hline
\end{tabular}

IX.sz. melléklet

Válogatott dokumentumok a vizsgált oktatási intézmények tanulmányi szabályzatai, tantervei, tájékoztatói közül.

1. www.akademiapz.sk a Szlovák Rendör Testületi Akadémia honlapja.

Studijná prírucka, Akademicky rok 2010/2011. [A 2010/2011. akadémiai év tanulmányi szabályzata.] Bratislava, 2010, Slovenská policie akademie deska. SK ISBN -

2. www.hwr-berlin.de a Berlini Gazdasági és Jogi Föiskola honlapja.

Studienführer Pol B.A. SS 2011. [A rendőr bachelor képzés 2011. évi hallgatói tájékoztatója.] Berlin, 2011, Hochschule für Wirtschaft und Recht Berlin. DE ISBN -

3. www.polac.cz a Cseh Rendör Akadémia honlapja.

- The Police Academy of the Czech Republic in Prague, a tanintézet nyilvántartási szám nélküli kiadványa, 2010.

Karel NovosAD - Dana LuKESOvÁ - Helena Mudrová: Informace o studiu akademicky rok 2010/2011. [A 2010/2011

tanév tanulmányi tájékoztatója.] Praha, 2010, Policejní akademie České republiky. CZ ISBN 978-80-7251-330-7.

4. Hallgatói Tájékoztató, 2009/2010. tanév. Budapest, 2009, Rendőrtiszti Főiskola. HU ISBN - 